\title{
Prospects for the Use of Liquefied Natural Gas as a Motor Fuel for Haul Trucks
}

\author{
Georgiy Dubov 1,*, Dmitriy Trukhmanov ${ }^{1}$, Iliya Kuznetsov², Sergey Nokhrin ${ }^{3}$, and Aleksey \\ Sergel $^{4}$ \\ ${ }^{1}$ T.F. Gorbachev Kuzbass State Technical University, Department of Mechanical Engineering Tech- \\ nology, Kemerovo, Russian Federation \\ ${ }^{2}$ T.F. Gorbachev Kuzbass State Technical University, Department of Building Structures, Water Sup- \\ ply and Disposal, Kemerovo, Russian Federation \\ ${ }^{3}$ LLC «Sibir-Energo», Novokuznetsk, Russian Federation \\ ${ }^{4} \mathrm{JSC}$ «BELAZ» - Management Company of Holding «BELAZ-HOLDING», Zhodino, Minsk region, \\ Republic of Belarus
}

\begin{abstract}
The state-of-the-art of efficiency and relevance of the use of liquefied natural gas as a motor fuel for truck operation is considered. A brief analysis of economic and environmental benefits of using liquefied natural gas as a motor fuel is conducted. It is noted that liquefied natural gas seems to be the most promising alternative to oil fuels for highpayload-capacity haul trucks. It is affirmed that for the first time in Russia, in Kuzbass, OOO "Siber-Energo" successfully implemented an integrated project for the production of liquefied natural gas and its consumption in relation to high-payload-capacity BelAZ haul trucks. The data on the assessment of the energy intensity of the process of rock mass hauling by high-payload-capacity BelAZ 75131 haul trucks equipped with on-board cryogenic fuel system are presented. The data show that the energy intensity of the process of rock mass hauling by dual-fuel (gas-diesel) haul trucks is much less than that of diesel-powered haul trucks. It is said that, according to the energy criterion for evaluating the operation, it is more efficient to use haul trucks running on gas-diesel mixture.
\end{abstract}

\section{Introduction}

The need for solid minerals in the world increases annually by $0.6-1.5 \%$. It is planned to increase coal production to 500 million tons per year by 2030 in the program for the development of coal industry in Russia. Achievement of these volumes is possible only with mining new deposits in Siberia and the Russian Far East. This will lead to a significant demand for fuel-efficient haul tucks meeting the increased environmental standards [1].

As a part of the full cost of mining and processing of minerals, hauling costs are one of the main components. The share of hauling operations can be $40-50 \%$ in the cost of mining. The efficiency of mining largely depends on the mode of transport used for rock mass hauling (truck, railway, conveyor, hydraulic, etc.), the choice of which is determined by mining

*Corresponding author: nikokem@mail.ru 
and geological conditions of a deposit. At present and in the near future, truck haul remains the main mode of transport for open-pit mining [2].

\section{Materials and Methods}

Today, Belarusian Automobile Plant supplies a large number of high-payload-capacity haul trucks to Kuzbass. About three thousand BelAZ haul trucks are used in the mines of the region, which makes up the majority of the entire high-payload-capacity haul truck fleet in the region.

The use of liquefied natural gas as a partial replacement of diesel fuel (gas-diesel operation) for high-payload-capacity haul trucks is advisable for the following reasons:

- haul trucks consume large amounts of diesel fuel (on average, 600-1500 liters per shift depending on carrying capacity), which largely determines the economy of mining production in terms of reducing the cost of one ton of mined minerals;

- haul trucks are operated along lacet roads on steep slopes of quarries and open-pit mines (at a depth of more than $200 \mathrm{~m}$ ); and because of the high angle of upgrades the haul truck engine is loaded to capacity at low speed, which leads to an increase in toxic emissions and fuel consumption 2-3 times [2].

- an increase in mining production contributes to increased energy consumption and exhaust emissions - the main pollutants in the areas.

The purpose of this study is to determine the prospects for the use of liquefied natural gas - methane, as a motor fuel for haul trucks.

\section{Results and Discussion}

As noted earlier, one of the ways to improve the economic and environmental situation in open pit mining is the use of alternative motor fuels. Natural gas, which can be used as a motor fuel without any deep processing, except for the stage of its production, shipment and liquefaction is recognized the economically viable alternative fuel [3-4].

Liquefied natural gas is used for diesel vehicles operated in France, the UK, Netherlands, Germany, Japan, and the USA. Recent studies carried out by Toyo Menka, MAN, Ford, Saviem, and others have shown the technical feasibility and economic efficiency of the widespread use of liquefied natural gas in motor vehicles, including truck haulage [4-5].

Natural gas, as a motor fuel, has the following advantages over diesel fuel [2, 4, 6-9]:

- the cost of gas is much lower than that of the equivalent in calorific value volume of oil motor fuel;

- conversion of trucks to natural gas does not require significant constructive conversion of an engine itself;

- engine power does not change;

- engine life becomes 1.5 times longer

- motor fuel consumption decreases by $20-30 \%$;

- overall transportation and operational costs are reduced;

- maintenance costs are reduced;

- the volume of toxic emissions into the air decreases by 2-3 times (emissions of nitrogen oxides are reduced by 2.5 times, carbon oxide - by 10 times, hydrocarbons - by 3 times, emissions of lead compounds, sulfur and soot are minimized);

- engine noise is reduced by $3-5 \mathrm{~dB}(\mathrm{~A})$;

- methane is the safest of all types of motor fuel, the temperature of spontaneous combustion of diesel fuel and gasoline is $250-300^{\circ} \mathrm{C}$, propane-butane $-450^{\circ} \mathrm{C}$, and methane $550^{\circ} \mathrm{C}$. 
Today, many countries are actively working on the conversion of haul vehicles - tractors, tugboats, drilling rigs, heavy-duty vehicles and haul trucks - to liquefied natural gas. For example, there are 240,000 heavy-duty trucks powered by liquefied natural gas in China, 5,000 in the United States and 1,500 in Europe. In Mexico since 2016 and in Turkey since 2018, the first Caterpillar haul trucks (with a load capacity of 130 and 220 tons) equipped with cryogenic onboard fuel systems are operated at gold mines [6, 10-14].

In Russia, the first integrated project for the production of liquefied natural gas and the conversion of high-payload-capacity BelAZ haul trucks to gas-diesel operation was successfully implemented by OOO "Siber-Energo".

During the project implementation in 2017, the first production train of natural gas liquefaction plant with a production capacity of 1.5 tons per hour was put into operation (Fig. 1). A refueling infrastructure was created, including modern mobile cryogenic refuellers and refueling areas that have no analogues in the Russian Federation (Fig. 2). The technical project for the conversion of BelAZ 75131 haul trucks (with a load capacity of 130 tons) to gas-diesel operation was developed with the scientific and engineering support of the scientists of T.F. Gorbachev Kuzbass Technical University. This technical project was approved by the haul truck manufacturer OAO "BELAZ". Several modifications of on-board cryogenic fuel systems for high-payload-capacity BelAZ 75131 haul trucks were developed and implemented within the project framework. As of May 2019, more than 50 BelAZ 75131 dump trucks they were equipped with onboard cryogenic fuel systems and successfully operated (Fig. 3).

Successful implementation of the project for the conversion of BelAZ 75131 haul trucks allowed in April 2019 to get approval from OAO "BELAZ" to launch the next innovative project to for the conversion of BelAZ 75306 haul truck (with a load capacity of 220 tons) to gas-diesel operation.

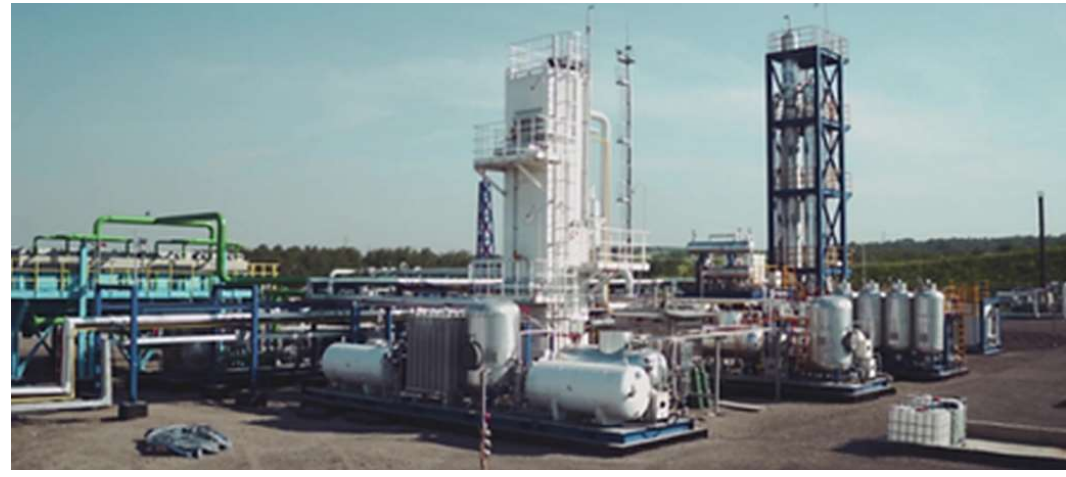

Fig. 1. Natural gas liquefaction plant (Russia, Novokuznetsk, OOO “Sibir-Energo”).

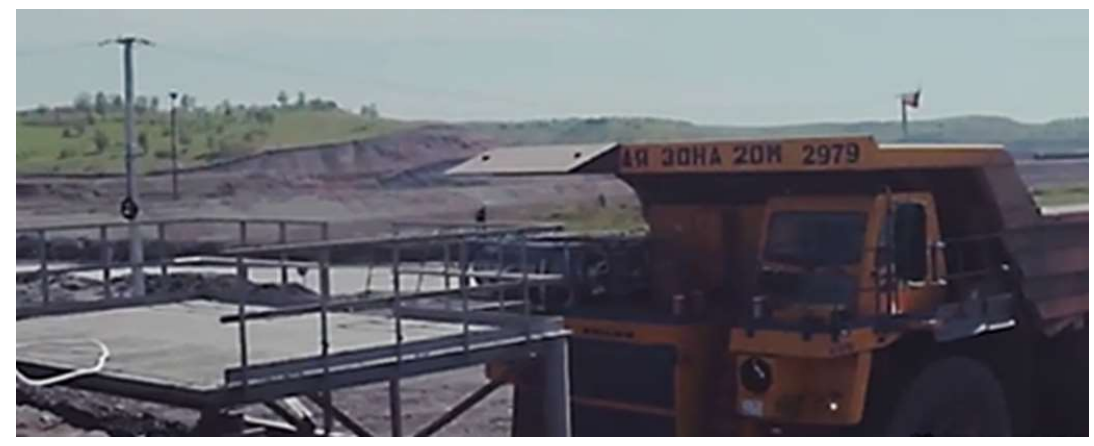

Fig. 2. Area for refueling haul trucks with liquefied natural gas. 


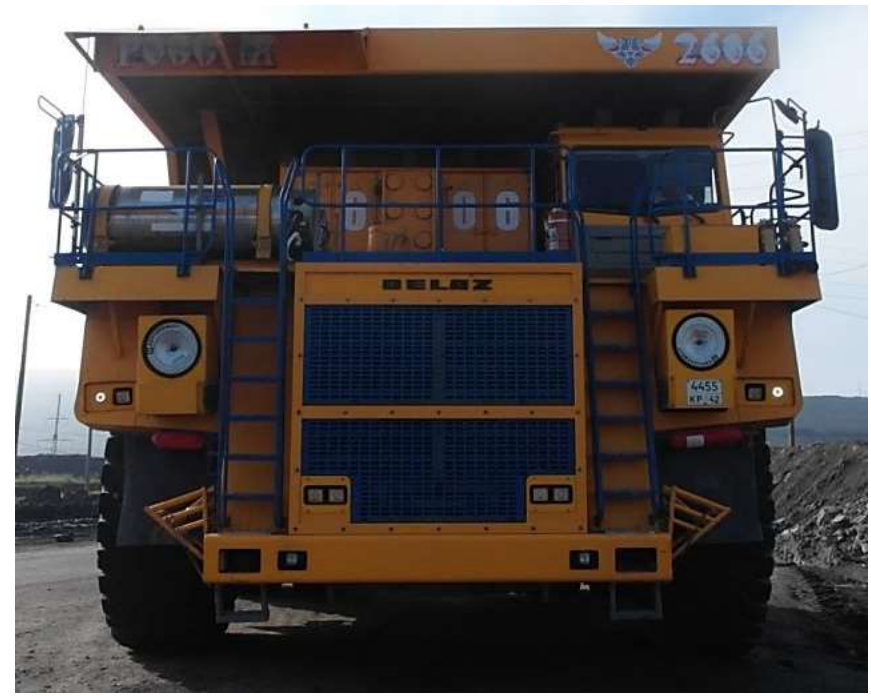

Fig. 3. High-payload-capacity BelAZ 75131 haul truck equipped with on-board cryogenic fuel system.

\subsection{Assessment of the energy intensity of the process of rock mass hauling by BelAZ 75131 haul trucks, equipped with on-board cryogenic fuel system}

A universal indicator of the operation of high-payload-capacity haul trucks is the energy intensity of the process of rock mass hauling. To assess the energy intensity of the haulage, the specific energy consumption was taken as the energy intensity measurement unit. Taking into account the fact that the modernized BelAZ-75131 haul trucks run on both natural gas and diesel fuel, the specific energy consumption will be calculated as follows [15]:

$$
P_{\mathrm{f}}=R\left(P_{\mathrm{f}}^{d . f}+P_{\mathrm{f}}^{n . g}\right)
$$

where $P_{\mathrm{f}}{ }^{d . f}$ - the specific energy consumption during the haul of 1 ton of rock mass per 1 meter using diesel fuel, (reference fuel gram/ton-meter $(\mathrm{r} \cdot \mathrm{f} \cdot \mathrm{g} / \mathrm{t} \cdot \mathrm{m})$ ); $P_{\mathrm{f}}{ }^{n \cdot g}-$ the specific energy consumption during the haul of 1 ton of rock mass per $1 \mathrm{~m}$ using natural fuel, $r \cdot f \cdot g / t \cdot m$; $R$ - the ratio of the distances that haul truck has run on gas and diesel fuels. la:

The specific energy consumption for diesel fuel is calculated using the following formu-

$$
P_{\mathrm{f}}^{d . f}=\frac{g}{i} k_{\text {rat. }} k_{\text {ext. }} k_{\text {cal. }}
$$

where $g-$ the specific diesel fuel consumption, $\mathrm{g} / \mathrm{t} \cdot \mathrm{m} ; i$ - the weighted average slope, \%o; $k_{\text {rat. }}$ - the refining ratio, taking into account the energy costs of producing diesel fuel from oil $\left(k_{\text {rat. }}=1,18 \div 1,20\right) ; k_{\text {ext. }}-$ the coefficient taking into account the energy costs of fuel extraction and transportation $\left(k_{\text {ext. }}=1,04 \div 1,10\right) ; k_{\text {cal }}-$ the coefficient taking into account the difference between the specific calorific values of diesel and reference fuel $\left(k_{\text {cal. }}=1,5\right)$.

The specific diesel consumption is determined from the expression:

$$
g=\frac{Q}{m l}
$$

where $Q$ - the diesel consumption, $\mathrm{g} ; m$ - the hauled load weight, $\mathrm{t} ; l-$ the haul distance, $\mathrm{m}$. 
In the case of natural gas engine operation, the specific energy costs are calculated as:

$$
P_{\mathrm{f}}^{n . g}=\frac{g^{\prime}}{i} k_{\text {rat. }}^{\prime} k_{\mathrm{ext} .}^{\prime} k_{\mathrm{cal} .}^{\prime}
$$

where $g^{\prime}-$ the specific natural gas consumption, $\mathrm{g} / \mathrm{t} \cdot \mathrm{m} ; k_{\text {rat. }}^{\prime}-$ the refining ratio, taking into account the energy costs of producing and liquefying natural gas $\left(k_{\text {rat. }}^{\prime}=1,2 \div 1,4\right) ; k_{\text {ext. }}^{\prime}-$ the coefficient taking into account the energy costs of gas recovery and shipment $\left(k_{\text {ext. }}^{\prime}=1 \div 1,3\right) ; k_{\text {cal. }}^{\prime}-$ the coefficient taking into account the difference between the specific calorific values of gas and reference fuel $\left(k_{\text {cal. }}^{\prime}=1,2\right)$.

The specific natural gas consumption is calculated similarly by the formula (3).

Plug the known coefficients in the formula (1):

$$
\begin{gathered}
P_{\mathrm{f}}=R\left(\frac{Q}{i m l} \times 1.2 \times 1.1 \times 1.5+\frac{Q^{\prime}}{i m l} \times 1.4 \times 1.3 \times 1.2\right) ; \\
P_{\mathrm{f}}=\frac{1.98 R}{i m l}\left(Q+1.1 Q^{\prime}\right) ;
\end{gathered}
$$

Formula (5) was obtained under the condition that the haul distances when burning diesel and gas fuels will be the same, which is practically impossible to in the at field. In this regard, the specific energy consumption of haul trucks equipped with on-board cryogenic fuel systems will be calculated as follows:

$$
P_{\mathrm{f}}=\frac{1.98 R}{i m}\left(\frac{Q}{l}+\frac{1.1 Q^{\prime}}{l^{\prime}}\right) ;
$$

where $l$ - the distance that the haul truck has run on diesel fuel; $l$ '- the distance that the haul truck has run on natural gas fuel.

\subsection{Analysis of the results obtained}

The data obtained in the process of monitoring the operation of BelAZ-75131 haul trucks (running on diesel and gas-diesel fuels were processed using the methods and tools of statistics. An example of the processing results is presented in Table 1.

Table 1. An example of the results of statistical processing of monitoring data.

\begin{tabular}{|c|c|c|c|c|c|}
\hline No. & $\begin{array}{c}\text { Distance, } \\
\mathbf{~ k m}\end{array}$ & $\begin{array}{c}\text { Load } \\
\text { weight, } \mathbf{t}\end{array}$ & $\begin{array}{c}\text { Weighted average } \\
\text { slope, \%o }\end{array}$ & $\begin{array}{c}\text { Specific energy } \\
\text { consumption } \\
\text { without on-board } \\
\text { cryogenic fuel } \\
\text { systems, } \\
\text { r.t.g./t } \cdot \mathbf{m}\end{array}$ & $\begin{array}{c}\text { Specific energy } \\
\text { consumption } \\
\text { with on-board } \\
\text { cryogenic fuel } \\
\text { systems, } \\
\text { r.t.g./t·m }\end{array}$ \\
\hline 1. & 3,74 & 132 & 75 & 48,326 & 41,889 \\
\hline 2. & 3,76 & 132 & 75 & 54,00 & 51,948 \\
\hline 3. & 3,77 & 132 & 75 & 49,29 & 40,476 \\
\hline 4. & 3,8 & 130 & 77 & 32,557 & 26,342 \\
\hline 5. & 3,81 & 130 & 77 & 54,1 & 53,402 \\
\hline 6. & 3,9 & 130 & 78 & 49,832 & 39,049 \\
\hline 7. & 4 & 134 & 82 & 45,867 & 33,424 \\
\hline
\end{tabular}

According to the obtained results, a radar chart was constructed, which clearly shows the energy efficiency of gas-diesel haul trucks equipped with on-board cryogenic fuel system (Fig. 4). 
The radius of the radar chart represents the axis of BelAZ-75131 haul truck specific energy consumptions values: dark area - haul trucks without on-board cryogenic fuel system (only diesel-fuelled), light area - haul trucks equipped with on-board cryogenic fuel system (burning gas-diesel mixture). Along the circumference is the axis corresponding to the ordinal specific energy consumption values. When calculating and constructing, the operation of haul trucks under identical conditions was taken into account.

From figure 4 it can be seen that the area of distribution of specific energy consumption during rock mass haul by haul trucks equipped with on-board cryogenic fuel systems is much less than that of haul trucks without them. Consequently, according to the energy criterion for evaluating the operation, it is more efficient to use haul trucks running on gasdiesel mixture.

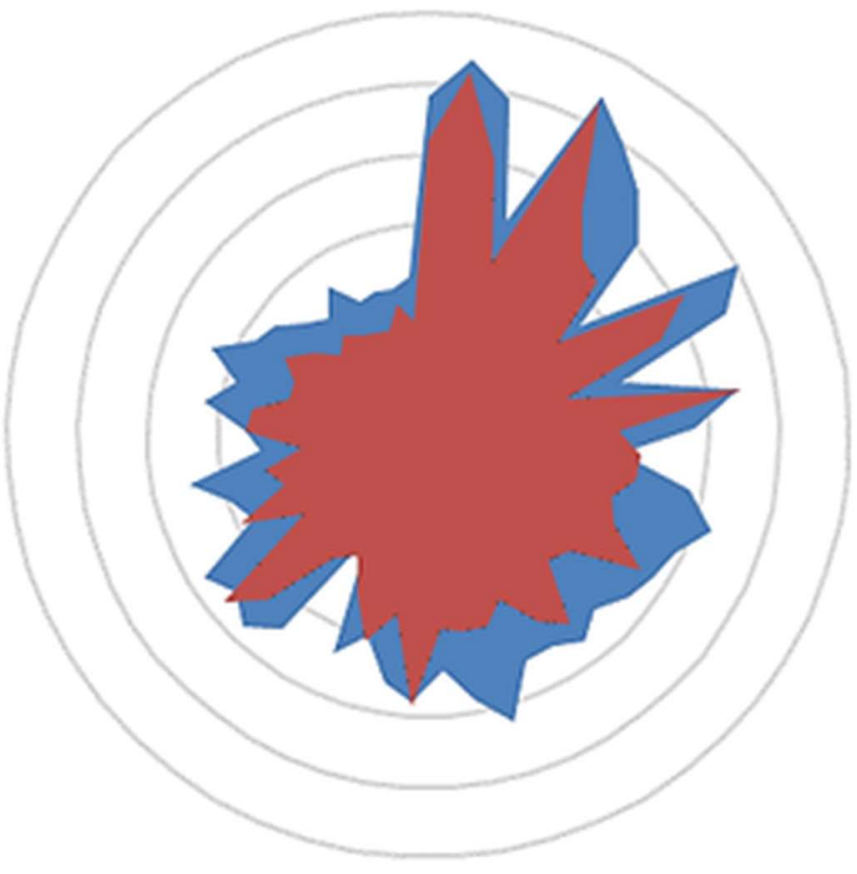

Fig. 4. Distribution of specific energy consumption by BelAZ-75131 haul trucks in operation.

\section{Conclusion}

The use of liquefied natural gas as a motor fuel for mining equipment today has great prospects. Liquefied natural gas is an alternative type of motor fuel that is significantly cheaper than diesel fuel. The use of liquefied natural gas does not require complex and timeconsuming constructive refinement of internal combustion engines. It is feasible for the use in haul trucks. It reduces environmental burden. The conducted studies suggest that the equipment of haul dump trucks with on-board cryogenic fuel systems is one of the promising areas for their modernization. However, the lack of sufficient technically and scientifically grounded decisions, as well as methods for assessing technical and economic indicators of on-board cryogenic fuel systems, hinders the work currently underway on the conversation of haul trucks to gas-diesel operation. Therefore, studies aimed at substantiating and selecting design and circuit solutions for the installation and layout of on-board cryogenic fuel systems in open-pit mining trucks in conjunction with mining, ergonomic and 
environmental requirements, as well as the subsequent study of their performance are relevant.

\section{References}

1. G.M. Dubov, D.S. Trukhmanov, A.A. Chegoshev, V.E. Ashikhmin, E3S Web Conf., 41, 03008 (2018)

2. M.L. Khazin, PJPME, 19:1, 56 (2019)

3. W.L. Litzke, J. Wegrzyn, SAE Technical Paper, 01, 2067 (2001)

4. J. Osorio-Tejada, E. Llera, S. Scarpellini, WIT Transactions on The Built Environment, 168, 235 (2015)

5. B.S. Vasilevich, R. Petrovic, M. Miljevic, I. Derdemez, DJMCS, 2:2, 001 (2016)

6. J.L. Osorio-Tejada, E. Llera-Sastresa, S. Scarpellini, Renew. Sust. Energ. Rev., 71, 785 (2017)

7. V.Y. Koptev, A.V. Kopteva, IOP Conf. Ser.: Earth Environ. Sci., 87:2, 022010 (2017)

8. K. Cheenkachorn, C. Poompipatpong, C.G. Ho, Energy, 53, 52 (2013)

9. H.A.A. Wahhab, M.A. Ismael, A. Aziz, M.R. Heikal, AJAS, 10:2, 88 (2017)

10. Y. Xing, H. Song, M. Yu et al. Atmosphere, 7:9, 121 (2016)

11. H. Song, X. Ou, J. Yuan, C.L. Wang, Energy, 140, 966 (2017)

12. P. Blomerus, P. Oulette, $L N G$ as a fuel for demanding high horsepower engine applications: technology and approaches (Westport Innovations Inc., Vancouver, 2013)

13. M. Hu, W. Huang, J. Cai, J. Chen, AIME, 9:6, 1687 (2017)

14. J. Li, B. Wu, G. Mao, Journal of Natural Gas Science and Engineering, 27, 945 (2015)

15. I.V. Kuznetsov, I.A. Panachev, G.M. Dubov, S.A. Nohrin, Handbook. An Engineering Journal, 4, 19 (2019) 